\title{
EchoGéo
}

$20 \mid 2012$

Des mobilités aux transports. Regards croisés en Afrique de l'ouest

\section{Reflections on a century of road transport developments in West Africa and their (gendered) impacts on the rural poor}

\section{Gina Porter}

\section{OpenEdition}

Journals

Édition électronique

URL : https://journals.openedition.org/echogeo/13116

DOI : 10.4000/echogeo.13116

ISSN : 1963-1197

Éditeur

Pôle de recherche pour l'organisation et la diffusion de l'information géographique (CNRS UMR 8586)

Référence électronique

Gina Porter, «Reflections on a century of road transport developments in West Africa and their (gendered) impacts on the rural poor », EchoGéo [En ligne], 20 | 2012, mis en ligne le 13 juillet 2012, consulté le 10 août 2021. URL : http://journals.openedition.org/echogeo/13116 ; DOI : https://doi.org/ 10.4000/echogeo.13116

Ce document a été généré automatiquement le 10 août 2021.

EchoGéo est mis à disposition selon les termes de la licence Creative Commons Attribution - Pas d'Utilisation Commerciale - Pas de Modification 4.0 International (CC BY-NC-ND) 


\title{
Reflections on a century of road transport developments in West Africa and their (gendered) impacts on the rural poor
}

\author{
Gina Porter
}

\section{Introduction: roads, poverty and gender}

1 This paper takes a long view. It is concerned with tracing road construction and associated transport developments over the last century in two countries, Ghana and Nigeria, and assessing their impact on the rural poor in different periods, with particular reference to rural women. These countries provide very interesting case studies for comparative research because of their shared experiences as former British colonies, but their often contrasting economic histories, associated with factors such as differing resource endowments, size and post-Independence patterns of rule. In looking to assess the impacts of roads and transport developments on the rural poor, I intend to focus particularly on women, since rural women in West Africa generally experience much higher levels of poverty than men, as numerous studies attest. Despite the attention now paid to gender issues in development, gender has not been adequately mainstreamed into infrastructure and rural transport services policy and practice. Thus, while there has been a fair amount of gender 'box-ticking' in the transport sector in Africa in recent years, there is still remarkably little serious engagement with addressing women's transport problems (Fernando and Porter, 2002; Porter 2008, 2011). I will also consider differences between roadside and off-road impacts of road construction and maintenance projects. My aim is to draw attention to two continuing gaps in the roads literature on Africa: the shortage of gender-disaggregated research on road impact and the tendency for impact studies to concentrate on the immediate roadside only. 
2 Archival studies in Ghana, focusing on Central Region, provide illustration of trends in road construction and transport development in the colonial and early postindependence periods. Contrasts are then drawn with Nigeria's road construction and transport history, with particular reference to the oil boom period of the 70s and early 80 s and the subsequent structural adjustment programme, drawing on work I have previously published on this theme and, in Ghana, on secondary sources. This is followed by a summary of road transport conditions and their impacts over the last two decades, drawing principally on personal ethnographic fieldwork. For each period attention is drawn to the impact of broad roads policy and transport/access realities on rural women, but I focus on overall trends rather than exploring rural women's own perspectives or (re)presenting their voices (since this material is available in previously published case studies). My aim throughout is to identify broad patterns, rather than detailing findings for particular phases. The study concludes with a brief discussion of recent donor-influenced policy shifts, for instance towards greater emphasis on (labour-based) road maintenance and, for a time, the promotion of Intermediate Means of Transport, and considers the implications of such developments for the rural poor.

3 Particular attention is given throughout the paper to impacts on rural women in their role as traders, since small-scale trading of farm and other produce is a major occupation and source of livelihood for rural women across most of the sub-region. Within this group I focus particularly on petty traders i.e. the majority of women who do not belong to well-resourced elite groups. Underlying themes are:

- that roads in West Africa are not necessarily 'a good thing' for women who live by them, because they are often not in a position to take advantage of the benefits that the road confers.

- that for women (and other sectors of the rural poor) who live away from good roads, regional road construction programmes can actually make life even harder.

\section{Road construction in West Africa over the last century and its impact on the rural poor}

4 A historical review of road construction over the twentieth century is important in understanding contemporary provision and its impacts across the region. The broad imprint of road policies developed in the colonial period is still evident in current patterns of provision, despite subsequent developments. Certain legacies of the colonial period, notably forced labour on roads, also have some bearing on current attitudes to road ownership and maintenance. Four major phases of road provision and transport services development in West Africa can be identified:

1. A colonial phase, where the emphasis was on accessing major export producing areas.

2. A post-Independence phase (1960s to 1980 s) when newly independent governments began to shape their own road and transport policies. Following the 1973 hike in oil prices these policies were strongly influenced by the divergence in economic fortunes which occurred, depending on whether the country was an oil importer and thus faced serious recession (Ghana - and most of West Africa) or experienced boom as an oil exporter (Nigeria). Subsequently, recession spread to Nigeria, too, as world oil prices collapsed in the early 1980s. 
3. A structural adjustment phase from the mid 1980s which influenced conditions for well over a decade. External interventions in this phase from the IMF and the World Bank brought increasing influence to bear on local policy and conditions in both countries.

4. A new phase of (mostly) more positive change for both Ghana and Nigeria in the $21^{\text {st }}$ century, such that Ghana is now newly classified as a lower middle income economy (and hopefully will benefit from the exploitation of important oil reserves in the Western Region), while Nigeria continues to exploit its oil reserves and has benefited from a somewhat improved political scene, resulting in an ambitious reform agenda and mostly strong economic growth (notably between 2003 and 2010). These developments have attracted new donors and investors to both countries, with impacts on both road infrastructure investment and the transport services sector.

\section{Colonial developments}

5 In the colonial period, across West Africa, basic transport infrastructure investment focused on opening up the region for political and economic purposes, particularly mineral exploitation. This had tremendous implications not only for movements of goods and services, but also for the levels of development in the various rural regions through which major lines of communication passed, or ignored. In most West African countries (excluding those which are land-locked), there was essentially a coastal and southern export zone and a northerly zone which was substantially less developed unless favoured by the presence of exploitable resources. Northern areas tended to become labour reserves and regions of neglect. But even in coastal areas where communications were developed, the impact of improved access on rural people varied substantially according to their precise location and economic status.

This is well illustrated by reference to southern Ghana which saw much activity in road construction, with cocoa the catalyst for expansion. In addition to colonial government works, initiatives on road construction were also taken by local communities where economic incentives were apparent (e.g.Hill 1970: 28), but the degree of control exercised by government over roads (including use of forced labour from villages) and its potential negative effects in terms of concepts of local ownership and responsibility for roads is clear. Political officers leaned heavily on - or directly ordered - local communities to provide free communal labour (e.g. CCRA ADM 23/1/405 1925 Quarterly Report, Bereku-Koshua road). Overall, the influence of road construction on population distribution and cultivation patterns was substantial. Reviewing road conditions in Ghana shortly after independence (1957), White (1962) observed the remarkable impact of roads on surrounding populations: 'the cutting of a new road will have an immediate effect on the pattern of land use and settlement....[and] attracts villages to the roadside, while the land within easy reach of the road becomes more extensively cultivated. Thus the land use pattern tends to take on a ribbon-like appearance, the zones of cultivation aligned along the roads'. In the case of a road in Western Region, the movement of populations was so large that 'in areas remote from the road cultivation has almost ceased'. Very similar patterns - with similar impacts - were evident in Nigeria (and probably across West Africa).

\section{Road construction and the rural poor in the colonial period}

7 The evidence from coastal Ghana suggests that the rural poor contributed substantially to road construction and improvement through forced labour and exercised no control 
in the selection of routes. In those settlements which contributed labour along the new routes, some local elites and resourceful farmers benefited from passing trade and the opportunity to become involved in the cocoa export trade, others in the new opportunities offered by the transport industry. But it can be fairly confidently assumed that those who contributed forced labour mostly constituted a rather different population from those with sufficient resources to benefit from investment in export agriculture. Landowners clearly benefited most from the cocoa boom, as they were able to enter into highly advantageous sharecropping agreements with landhungry migrant farmers, a practice which spread widely from the 1920s (Amanor 1994: 45-6).

Gender patterns do not figure substantially in colonial reports on road developments in southern Ghana, where reference is mostly commonly made to (genderless) 'natives': there is no specific evidence to suggest whether various groups of women in coastal Ghana benefited from road construction or not. As the principal headloaders here, as in most regions of West Africa, women and their children resident in roadside settlements may have benefited from the expansion of motorised transport (since porterage is usually an unremunerated duty of wives and daughters), but the focus of roads development in areas with potential for export production presumably increased demands on them for transporting produce to the roadside and other labour tasks as the momentum in export production grew. Some women probably did benefit from the new opportunities offered as roads penetrated the interior: for instance, Nigeria's Ibo women vegetable oil producers who grew wealthy in the 1920s, but a more common pattern seems to have been for women to suffer as the commodification which accompanied road penetration increased. In eastern coastal Ghana, for instance, Greene $(1996 ; 180)$ concludes that women lost their economic independence, due to declining access to land, which reduced their ability to participate as independent farmers in commercial agriculture. In such conditions little benefit could have accrued to most women from the road developments with which commercial production was intimately bound.

\section{The early post-Independence period}

9 The early post-Independence period of the 1960s and 70s saw some divergence in patterns of transport development in West Africa, according to the potential of individual local economies and to political conditions. This is well illustrated by a comparison of countries like Ghana - where an economic downturn soon set in - and Nigeria where, after a phase of civil war, revenues from oil eventually led to a period of remarkable - if ephemeral - economic boom.

In Ghana, after independence in 1957 there was relative stagnation. In Central Region this was associated particularly with the decommissioning of all its surf ports following the completion of Tema harbour in 1962. Local urban populations along the coast lost income and the cost of transport to ports for local produce increased. As the economy deteriorated, here and elsewhere in Ghana, in the 1970s - arguably partly the result of over-regulation of markets, evidenced in efforts at price control in foodstuffs and taxation of export crops - roads deteriorated substantially, as did the number and condition of vehicles. Travel problems were compounded by petrol shortages. According to Clark (1994:66), farmers and rural-based traders in the Kumasi region at 
this time had difficulty persuading drivers to take their vehicles on poor roads to collect produce and 'many villages fell off the transport map entirely'. She suggests that major centres benefited to an extent, because traders in smaller centres had to spend much time searching for vehicles (ibid: 70, 207). Eventually, in the 1970s, even major trunk roads were deteriorating, so restricting the activities of the major urbanbased traders and further reducing the markets accessible to rural women.

11 In Nigeria, as in Ghana, colonial road construction programmes had focussed on the south - in this case Lagos and the Western Region - and were closely associated with the expansion of export crops (Ekundare 1973: 267). However, oil resources brought a spectacular - if short-lived - development in transport infrastructure and services following the hike in oil prices in 1973. 1975 was a year of particular significance in terms of accessibility, because massive back-dated pay awards in both public and private sectors - a direct result of the boom - brought motorbike and vehicle purchases, for the first time, within the reach of many ordinary working Nigerians. And many more could afford transport fares for the first time. The benefits of vehicle ownership extended to the rapidly growing entrepreneurial group of owner-drivers who started taxi and mammy-wagon services, thus providing an expanded transport service to (accessible) rural populations. As Guyer vividly describes, the oil-boom impact was both rapid and dramatic: in the Western region 'even relatively poor farmers at the end of the capillaries of distribution found that they could afford a motorcycle... '. This was the era when the Datsun pick-up arrived, aptly named, in Yoruba, the jalukere ('let's go into the potholes'). By 1977 annual imports of this kind of vehicle reached nearly 31,000 (Guyer 1997: 86). Elsewhere in Nigeria, where large areas remained remote from paved roads, a massive all-season road building programme commenced, focused on interurban connections. In tandem, there was an estimated doubling of vehicle numbers between 1976 and 1982. The two mutually reinforcing elements of road construction and rapidly increasing vehicle ownership contributed both to major urban expansion and to rural reorganisation, with significant repercussions for people across the country.

Even in the remote far north-eastern corner of Nigeria, the impact of improved access on rural areas was notable: within days of a road construction team setting up camp in a new area, flimsy shade covers would be erected and women from nearby settlements would begin to set up food stalls. This was often followed by the construction of first temporary, then permanent, dwellings: settlements subsequently rapidly established themselves along the new all-season paved roads. The small collection of food stalls, following the opening of the road, could rapidly transform into a thriving new market, which would link in to the city markets down the road. It is not surprising that road construction - viewed from the tar - is often seen as the harbinger of positive change in regional economies, and with positive benefits for women. One of the most interesting components of road construction impact, however, is what happens away from the paved road. Only a few kilometres from the road, a substantially different picture of change could emerge: a picture not merely of stagnation, but even decline. A series of detailed studies in Borno, in 1978 through to 1984, enabled me to build up a picture of rural change across four districts (Porter 1988). Here the impact of the road construction and up-grading programme and the associated massive increase in transport ownership was to encourage a remarkably rapid redistribution of population to the roadside. In this remote semi-arid region, whole settlements decamped thus 
recalling White's (1962) observations above of earlier road impact in off-road areas in western Ghana.

The impact of this movement on off-road rural economies - reflected in marketing patterns - was arguably particularly important in Moslem Borno, because it had a specific impact on rural women who very commonly made a living from trading in petty goods in rural markets. Between 1978 and 1984 seven remote rural periodic markets in my study area totally collapsed and others went into serious decline because of a refocussing of marketing on roadside markets, further encouraged by enforcement of government policy regarding closure of small markets (small markets were thought to divert trade from major markets, where market tolls - a source of local government revenue - are more easily collected from traders). Many rural women interviewed in the late 70s had earned their living from childhood by engaging in petty trade in rural markets. However, women below the age of menopause were not expected to travel more than a few kilometres, to trade in their local market. Most women, in any case, could not afford transport - even if it were available - to travel further. They engaged in a very localised petty trade, mostly selling goods they had produced or gathered themselves. Men, by contrast, travelled further and more frequently to trade and sold higher value produce. The disappearance of off-road markets meant that opportunities to visit market were severely curtailed for the women living nearby who patronised them: travel to more distant places took much longer and could, in any case, affect their reputation, because of the association between long-distance travel and immorality (Porter 1988, 2011). The decline and disappearance of off-road markets in this region was a direct consequence of road construction. For women and other less mobile groups such as the elderly, who remained resident in remote off-road settlements, the impact of market loss was enormous, given the crucial significance of trade as a source of diversifed income in this region of limited agricultural potential.

\section{Road transport and rural access in the era of Structural Adjustment: the 1980 s and 90 s}

14 By the early 1980s, much of West Africa was clearly suffering severe recession. IMF / Bank packages were -albeit reluctantly - gradually accepted by most countries. Ghana came first in 1983, but Nigeria followed perhaps surprisingly rapidly, in 1986, with a 'domestic' SAP, as a consequence of the collapse in oil prices. Considerably later other countries like Burkina Faso and Sierra Leone followed suit. The early phase of structural adjustment - which saw implementation of currency devaluations, elimination of subsidies and reduction of state intervention in the economy - brought immediate problems in the road transport sector in West Africa (as elsewhere). Roads deteriorated rapidly because of the shortage of funds for maintenance, vehicle purchases declined as a result of the escalating costs of imported vehicles, spare part supplies declined for the same reason, and much pressure was placed by the Bank to force cuts in fuel subsidies. However, the degree to which SAP impacted on local economies and people's lives varied to some degree between countries and sectors.

15 In terms of country variation, interesting comparison can be drawn between Nigeria and Ghana. Essentially, Nigerians felt the impact of SAP dramatically whereas, by contrast, Ghana had been in severe recession for many years: in 1988 only $28 \%$ of Ghana's roads were reportedly in good condition, compared to $67 \%$ in Nigeria. Both its 
road stock and its vehicle stock (mostly composed of second-hand imports) were in much poorer condition than Nigeria's. Funds for road maintenance in both countries were still being regularly spent on expensive improvement and emergency works rather than on routine maintenance.

Subsequently, following calls for governments in sub-Saharan Africa to recognise the limits to paved road construction and concentrate on lower-cost feeder roads (e.g. Beenhakker 1987), there was some change in emphasis in roads policy in Ghana. The 90 s thus saw a stronger focus on feeder roads development, supported by the World Bank, but given the enormity of the problem, the condition of rural roads generally remained a constraint on agricultural expansion.Nigeria's relations with donors were even more strained than Ghana's over the 15 years from 1985-2000 and donor investments in road rehabilitation programmes under SAP consequently less sustained. A Directorate of Food, Roads and Rural Infrastructure, established in 1986 to rehabilitate rural feeder roads, accomplished little because it was dogged by corruption, escalating construction costs and inadequate supervision. In 1991 I undertook a marketing/access study in three former tin-mining districts on the Jos Plateau. This suggested that the impact of SAP on rural marketing patterns at that stage had been to reinforce the significance of roadside locations, especially recently constructed roads which remained in good condition (Porter 1994, 1995). Transport owners and traders had become increasingly reluctant to take their vehicles beyond good quality paved road because of the difficulties of obtaining spare parts and the soaring cost of second-hand vehicles. So long as sufficient business could be found on a motorable paved road, no transporter would risk his vehicle operating off-road routes.

In Ghana, by the early 90s, SAP measures such as deregulation of fares, fuel and parts imports had reportedly brought some improvement in rural transport services, even on many minor roads. Clark (1994: 67-8, 212, 397) suggests this had positive implications for rural trade, since (urban-based) traders could more easily purchase from farms, rather than having to buy at (roadside) periodic markets, and farmers could themselves more easily bring their produce direct to a major market. This would presumably have had some beneficial impact on women traders and possibly also on off-road populations as a whole. Nonetheless, poor rural road conditions and associated high transport costs were identified as the single most important factor affecting the ability of subsistence farmers to enter the market economy in the World Bank's 'Ghana 2000 and beyond' review (1993). Rural Ghana was described in that review as largely a 'footpath economy'. It was one in which human porterage (mostly accomplished by women and their children) prevailed but brought serious (little researched) health risks and was a massive constraint on rural labour supply, also adding substantially to both production and marketing costs.

In Nigeria, by contrast, the early impact of SAP was to focus traders even more firmly on those paved routes still in reasonable condition due to infrastructure investments in the oil boom. The consequent impact in off-road areas of the Jos Plateau was severe, but unlike the case of the Borno Kanuri, the indigenous Birom in this region imposed no restraints on women's mobility. The decline of off-road markets and transport services on the Plateau (which had commenced in the oil boom) thus simply meant that an increasing number of women had to headload village produce further, to the roadside. Even so, the impact of off-road transport decline clearly disadvantaged off-road women 
who are expected to undertake porterage tasks for their husbands and male family members (Porter et al. 2003).

Exactly a decade after my 1991 markets study on the Jos Plateau, Nigeria, I returned to repeat the survey. Conditions by early 2001 had - in some respects - changed markedly. Transport availability in the rural market settlements was observed to be vastly superior to that available in 1991 in both on-road and most off-road villages, even where roads were (as most remain) bad. This was, in many cases, directly attributed to the expansion of irrigation farming and the money this brought into the villages. But there was a remarkable increase in vehicle numbers over the Plateau as a whole, at the start of the new century, due to decreasing import duties on second hand cars and the increased availability of cheap imported Chinese motorbikes, and the emergence of motorbike taxi services (achaba - meaning 'going') in both roadside and many off-road villages. Where roads were particularly bad, achaba reportedly provided a lifeline for villagers, being used in emergencies, or when people had missed the morning bus or when there was no market bus. Ironically, given Nigeria's continued status as a major oil producer, intermittent petrol shortages continued to represent one of the main transport problems facing all motorised transport owners and operators. (Field study in mid 2004 confirmed this pattern, but sadly, intermittent violence on the Plateau subsequently has disrupted further development - and research- in this region.)

One of the most important points which the Jos Plateau transport development emphasises is that, if sufficiently strong economic incentive and imperative exists (high-value perishable produce in this case), transport will generally be found, however difficult the road conditions. But this will not necessarily benefit women. Despite the improvements in transport ownership and use of both motorised and intermediate transport on the Plateau, most women in off-road areas were still walking to market in 2001: the impact of improved transport had principally benefited men, who owned the vast majority of vehicles. This is to be expected, given that the incomes from increased dry season agriculture had generally gone to men rather than to women: few women had the resources to invest in irrigation pumps.

21 Motor vehicle ownership was far higher in off-road villages on the Jos Plateau than in the off-road villages in Ghana's Central Region, where I also conducted research on market access for women traders in the late 1990s and early 2000s. Despite donor investment in Ghana, it did not have the stock of infrastructure (nor, perhaps, the expectations) that Nigeria had built up in the oil boom. Commonly, the few off-road people who owned motor vehicles - mostly men - stationed their vehicle at the roadside in order to earn money through provision of taxi services (Porter 1999). Roads were still bad and agricultural production (cocoa, maize, cassava, and some rain-fed vegetables) was insufficiently buoyant to encourage regular off-road services. Shortages of transport and unreliability of available (mostly imported, second-hand) transport continued to be defining features of the Ghanaian transport scene. This has shaped women's trading practices. In most circumstances in Ghana, traders have commonly had to escort their goods from place to place and supervise loading and unloading, because of vehicle unreliability and also in order to avoid theft and excessive transport charges and reduce spoilage. They must arrange and finance transport, but arranging transport in conditions of transport shortage can require a high labour investment in searching for vehicles and negotiating their use (Delaquis 1993, cited in Sieber 1997). Clark (1994) found some villages fairly near Kumasi but on 
very bad roads 'practically unable to sell fresh produce': there were also more intermediaries involved in produce sales in such locations than would be expected in settlements near a major market centre. The same situation still obtained in Central Region in the early 2000s: it was not only in 'remote' places far from a major town that accessibility was a serious issue for farmers. Accessibility to markets was probably almost as great a problem for most of Central Region's farmers and traders in 2002 as it had been at the start of the 1980s.

Obviously this has implications for women in their role as (mostly small-scale) traders. As Clark noted, supply of transport has a critical role to play in deciding the balance of power in driver/trader interactions (ibid: 209,211). On routes where transport is restricted, the potential for overcharging farmers and traders is great. Commercial drivers tend to be male and women traders rarely have sufficient funds to buy a truck. Transport negotiation is a widespread problem for women traders such that, 'the interaction between Ghana's female petty trader and the informal public transport system is, like much of Ghanaian life, one of bargaining, negotiation, preferencing and patronage: brokerage is at the heart of the Ghanaian public transport system' (Grieco et al. 1996: 13). For women who reside in off-road locations, bargaining power is usually particularly low and they and their children thus continue to play a major in headloading goods to market (Porter 2011; Porter, Blaufuss, Acheampong 2011, 2012; Porter et al. in press).

\section{Change after 2000 and its impact}

23 A new phase of (mostly) more positive change for both Ghana and Nigeria seems to have gradually emerged in the first decade of the $21^{\text {st }}$ century. This is reflected in (and reflects) the fact that Ghana is newly classified as a lower middle income economy, while Nigeria is benefitting from its oil reserves and a somewhat improved political scene, resulting in an ambitious reform agenda and mostly strong economic growth (though this has to be set against oil price volatility and widespread youth underemployment).

Although road infrastructure in both countries still leaves much to be desired, with many roads in poor condition, both countries have been attracting new actors and interventions in the infrastructure sector. Donor policies have, to an extent, been refined and - following outcries about the deleterious impact of adjustment on the poor and the institution of various Poverty Reduction Strategy Programmes and related interventions - more attention is being paid to mitigating the impact on poor populations while focusing on growth. Consequently, the EU/World Bank funded SubSaharan Africa Transport Programme (SSATP) instituted a participatory Pro-Growth, pro-Poor strategy from 2003 (PGPTS; see Braithwaite 2003). Moreover, new players are increasingly in evidence. In Ghana, aid from donors such as the Japanese has brought improvements in the rural infrastructure sector (bridges and roads), while in Nigeria, Chinese investment is increasing particularly rapidly. The arrival of the Chinese on the infrastructure scene in Ghana and Nigeria, bringing their own contractors and a different attitude from other donors, mirrors developments elsewhere in Africa (Turner et al. 2011). They have also consolidated their dominance in the transport services sector (along with Indian manufacturers) with cheap bicycles, buses, cars and especially in Nigeria - motor cycles. In Nigeria, motor-cycle taxis are now a widespread 
feature in rural and urban areas alike. In conjunction with this rapid expansion of motorcycle taxi- services over the last decade, mobile phone networks and widespread phone ownership look set to significantly change the organisation and use of rural transport services, particularly in the Nigerian context where motorbike taxis are prevalent. However, the impact of the mostly young, often inexperienced, drivers on road accident incidence has been extremely high: see Alti-Muazu and Aliyu 2008, Adogu et al. 2009). Interestingly, in Ghana motorbike-taxi services are still uncommon, though small groups of youths have been operating in Accra and elsewhere since at least 2009: government attitude to this development is distinctly unfavourable, with strong concerns expressed about road safety (Ghanaian Times, 4 April 2009: http:// www.modernghana.com/news/209796/1/no-okada-motor-bike-taxi-service-in-

ghana.html.In both countries, however, the very rapid expansion of mobile phone networks into even some quite remote areas has brought substantial benefit to the produce trade sector, where many women operate. This is already improving conditions in terms of ensuring safe transit and receipt of goods and thus has particular significance for women traders who may benefit from travel reductions (see Overå 2006, 2008 for Ghana, though unfortunately, mobile phones also have the potential to make highway robbery more efficient!). Mobile phones do not remove the need for all face-to-face interactions, but often allow traders to save money on fuel, bus fares, remuneration of intermediaries and their own time: they also enable communication on the road, when warning of delay or a call for help may be made in the event of accident, vehicle breakdown, robbery, harassment by rent-seeking officialdom etc.

\section{Reflecting on recent donor schemes for improving mobility and access for the poor in West Africa}

25 With growing recognition of the inequalities in access to transport, from the $90 \mathrm{~s}$ onwards various efforts have been made by donors to ameliorate the transport situation for poor groups - particularly women - in West Africa. This has being done through policies such as targeted IMT schemes and the expansion of labour-based (as opposed to machine-based) road work. However, targeting is difficult to effect in practice. Thus, although participatory assessments have become mainstreamed in the transport sector through the work of groups such as the SSATP, actual positive impact on the poor remains difficult to achieve.

\section{Labour-based road construction}

Labour-based construction has been widely encouraged in West Africa by donors, on the basis that it is a cost effective means of improving rural infrastructure which also generates rural employment, uses local resources thus saving on foreign exchange, injects cash in to local economies, transfers technical knowledge of road construction to the local community (which can be utilised in subsequent maintenance) and reduces environmental damage (Stock and de Veen 1996:v). Some aspects of the labour-based construction approach in sub-Saharan Africa have been perceived to need refining over time - notably improved financial management and decentralisation - but the value of the programmes to rural populations appears to be unquestioned by the World Bank Rural Travel and Transport Programme (RTTP), one of the leading promoters of labour- 
based methods which still promotes labour-intensive construction using small to medium size contractors (Thompson 2011).

Ghana was the first country in sub-Saharan Africa to introduce a country programme of labour-based methods for the local road contracting industry (ibid.1996:35). The first pilot programme was started in one of the cocoa areas of Western Region in 1996 by the Department of Feeder Roads with a World Bank credit. A specific aim of this road rehabilitation project was to utilise an 'underemployed local labour force ready and willing to improve the access to the villages' by creating employment for men and women. Subsequently the programme was expanded so that by 1995 it encompassed all the country's administrative regions. However, in a review I conducted in 2001 in Ghana, I could not find any specific statement in any of the DFR documentation as to the extent to which women had been employed in labour-based road works. In theory, the advantages of a labour-based approach include its considerable potential to benefit the rural poor living in the vicinity of a road targeted for construction or rehabilitation in terms of direct payment of wages, circulation of this cash in the local economy, and the acquisition of technical expertise in road construction and maintenance. However, in practice, contractors may bring in labour from elsewhere. The incidence of labour importation is mentioned in Stock and de Veen's RTTP review, but only as an appendix. They specifically refer to the Ghanaian case where migrant labourers are called 'old hands' and 'represent 10 percent to 30 percent of a contractor's labour force.' Contractors, they observed, find two advantages in using these people, first they are willing to accept late payments because they have developed 'a relationship of trust' with the contractor, and secondly they transfer skills to local labourers (ibid.:66). Stock and de Veen suggest that 'employers are often not interested in hiring large numbers of migrant labourers, since their lodging is often the responsibility of the employer.'

This may well be the case in some regions, but there was substantial anecdotal evidence from villagers in Central Region around 2001-2 that contractors brought in the whole of their workforce from outside. Many local contractors were based in urban centres such as Cape Coast and it seems that they simply found it easier to use a regular (urbanbased) workforce. There still does not appear to be any detailed documentation for Ghana which supports the oft quoted contention that rural communities - including women - benefit substantially from implementation of labour-based approaches. The contractor practice of importing its labour force may still benefit a relatively poor sector of the population, but it will not inject much money into local rural economies, nor will it assist in transfer of technical skills or provide communities with a sense of ownership of their local road which might encourage them to maintain it in the future. If labour-based programmes have, as one of their priorities, assistance to the rural poor, including women, then contractor labour policy needs more careful monitoring (Quagraine et al. 2009).

\section{The potential of IMTs}

29 Another possible route to improved mobility and access for the poor is through Intermediate Means of Transport. By contrast with Asia, anglophone areas of Africa, in particular, have been remarkably slow to adopt low cost means of transport. (Striking differences have long been observed, for example, in the level of motorcycle usage as one crosses from Ghana into neighbouring francophone countries like Togo). Yet the success of the motorcycle (and the bicycle) in areas like the Jos Plateau illustrates its 
potential to transform rural access, especially for men (though safety is a factor which needs serious attention). In part, the slow pace of IMT adoption in areas like coastal Ghana probably revolves around lack of critical mass (Starkey 2001) and the implications this has for repair facilities etc. But it also reflects a view still common among policy makers in Ghana and elsewhere that IMTs are backward technology: infinitely inferior means of transport, suitable only for the less developed northern regions of the country (Ellis and Hine 1995). Donor interest seems to have waned as a result of poor experience of uptake, though the SSATP still makes reference to exploring IMT needs and its Long Term Development Plan 2004-7 included nonmotorised transport (Thompson 2011).

Women's ownership and use of IMTs is typically very low indeed in Africa, though since women and their children do much of the loadcarrying it would seem that IMT adoption would bring them substantial benefit. Where IMT schemes have been introduced in Africa, they seem to have mainly benefited men (Doran 1990, Bryceson and Howe 1993). There is very little data on the impact of low-cost transport on women and Doran (1990) argued that it will be important to consult women before developing IMT schemes for them since there have been various failed schemes. In northern Ghana, where bicycle trailers were introduced, the scheme was unsuccessful for a number of reasons, including the fact that lack of capital among villagers made it difficult for them to afford a bicycle plus trailer, even on easy terms (Salifu 1994). Starkey (2001:23) argues from the Northern Ghana project experience that the trailers were promoted without clear understanding of the social, economic and technical issues involved; that although initial responses to IMT demonstrations can be 'euphoric', careful participatory research is needed to establish likely costs, benefits, usage patterns and constraints; and that other poverty alleviation options to assist women should have been explored.

31 These points seem to have general relevance to the broader IMT debate. In the early 2000s, I led a small action research study to explore IMT impact on 5 villages in southern Ghana over an 18 month period. From this we learned not just how but also why women's stated preferences prior to an intervention may differ from actual patterns of adoption, about the potentially crucial role of labour availability to women for operating the equipment, and the potential significance for gender relations of linkages between the type of IMT introduced and the degree of personal mobility they offer to women (Porter, Blaufuss, Acheampong 2012). While more widespread adoption of IMT could have substantial positive impact on the lives of women and children, interventions needed to be planned and executed with great care.

\section{Conclusion}

Evidence from Ghana and Nigeria suggests that, throughout the last century, the rural poor - particularly poor women resident away from the gradually expanding paved road networks - have faced enormous transport/access hurdles. Access to markets, to services like health and education, to agricultural extension services, banking facilities and credit and, indeed, to centres of power, influence and information, have all been constrained by poor roads and poor transport services. In some periods and some areas, all-weather road access has improved: notably in the cocoa producing areas of Ghana during the cocoa boom, and across Nigeria during the oil boom. For those with 
assets, substantial benefits could accrue once a good road was available, if local and national (policy) conditions allowed the development of transport services. But for those with little access to resources - of whom women tend to form a major portion in West Africa - even access to the road may bring little benefit, because opportunities to gain from land speculation or increased farming/commercial activities are few. It is still extremely common across West Africa to see women trekking with heavy loads along heavily-trafficked paved roads because they cannot afford to pay transport fares. Indeed, among the few opportunities which commonly expand for resource-poor women in roadside locations, apart from petty trade in cooked foods etc. sold to passing travellers, is prostitution, with all the implications this carries in an era of HIV/ AIDS. But traffic accidents also increase, particularly on busy rural roads, and evidence from Uganda and suggests the costs of accidents bear principally - and heavily - on women as the main carers (Kwamusi, 2002). Only now is serious attention being focused on the massive problem of road accidents in Africa: the 2011-20 UN Decade of Action for Road Safety is long overdue, given the level of road accident deaths in both Ghana and Nigeria.

The impact of regional all-weather road construction programmes on off-road areas, however, can be even more negative. Not infrequently, such road developments have actually led to a reduction of transport movements (and sometimes of economic activity) in areas away from the paved roads, as observations from Ghana just after independence (White 1962), from north-eastern Nigeria in the oil boom and from Nigeria's Jos Plateau following the imposition of SAP, suggest. When transport stocks are small or declining, as in the early years of the SAPs, the impact of all-weather road construction is to concentrate transport activity even more strongly along the best routes to conserve vehicle life. This results in a reorganisation of economic life, very evident in the decline of off-road markets. For vulnerable groups - particularly women and their children, because they lack resources and are usually the (mostly unpaid) porters in West Africa - the impact is to expand work loads and reduce income-earning opportunities. More time is spent trekking with the produce of all family members to the roadside markets.

In looking to resolve these access issues in Ghana and Nigeria, the immediate focus of attention - of governments and communities - still tends to be on roads. The construction or improvement of roads and tracks so that they are accessible by motor vehicles all year round is usually a prime development target of villages off the paved road, in particular. This raises a number of issues, however, not least the limited budgets available for road construction and, as discussed above, how to spend those funds most effectively. Donor initiatives for a time refocused attention towards intermediate technology solutions in both transport and road construction, on the basis that they were more likely to benefit the rural poor whose transport needs are often diverse and dominated by subsistence-related journeys. But these initiatives also need careful monitoring to ensure they assist the populations at which they are targeted: the failure of individual projects - and, in particular, the failure to bring benefits to poor women - has discouraged many donors. Given the potential offered by big road construction programmes for corruption, there is also continuing in-country resistance among some key players to smaller-scale low technology approaches, which give less opportunity for misappropriation of funds. 
By comparison with much of Asia, West Africa's road and transport stock is still remarkably underdeveloped. In West Africa by the late 1970s, road networks had only been developed to a density of from around 0.01 (Mali) to $0.11 \mathrm{~km}$ (Nigeria) of road per square $\mathrm{km}$ of land area, compared with 0.35 in Bangladesh and $0.41 \mathrm{~km}$ in India (Platteau 1996). Today, far smaller proportions are paved than in Asian countries and most are in much poorer condition. The number of motorised vehicles per mile of paved road is far lower in West Africa than Asia and vehicle maintenance costs are far higher (over five times as expensive in Africa as they were in Pakistan, cited in Platteau 1996; these proportions have probably changed little). The range and quantity of IMTs found in West Africa is a fraction of that available in Asia: most new bicycles imported into Ghana and Nigeria are manufactured in India and China. The transformation of West Africa's transport system clearly represents an enormous challenge, both technically and socially. Despite the various tentative initiatives towards intermediate technology, the development of locally appropriate, viable rural transport strategies which can benefit the rural poor, especially rural women, has seemed, for many decades, frustratingly elusive. However, the situation may be changing: the remarkable expansion of mobile phone networks and their increasing integration with the more flexible transport afforded by motorcycle taxi services suggests the possibility that a new era may be commencing which offers improved opportunities at least for some of the rural poor. But the extent to which such developments will advantage poor rural women - whose activities are often constrained not merely by transport costs and availability but also by prevailing socio-cultural practices and mores - remains to be seen.

\section{BIBLIOGRAPHIE}

Adogu P O U, Ilika A L, Asuzu A L., 2009. Predictors of road traffic accident, road traffic injury and death among commercial motorcyclists in an urban area of Nigeria. Nigerian journal of medicine, 18, 4: 393-7.

Alti-Muazu M; Aliyu A A, 2008. Prevalence of psychoactive substance use among commercial motorcyclists and its health and social consequences in Zaria, Nigeria.Annals of African medicine, 7, 2, p. 67-71.

Amanor K.S., 1994. The new frontier: farmers' response to land degradation, a West African study. London: Zed.

Beenhakker H.L. et al., 1987. Rural transport services: a guide to their planning and implementation. London: IT Publications.

Braithwaite M., 2003. SSATP review of national transport and poverty reduction strategies: guidelines. SSATP Working Paper no. 77, December 2003.

Bryceson D.F. and Howe J., 1993. Rural household transport in Africa: reducing the burden on women? World Development 21,11, p. 1715-1728. 
Clark G., 1994. Onions are my husband: survival and accumulation byWest African market women. Chicago: University of Chicago Press.

Doran J., 1990. A moving issue for women: is low cost transport an appropriate intervention to alleviate women's burden in sub-Saharan Africa. Norwich: School of Development Studies, University of East Anglia, Gender analysis discussion paper no. 1.

Ekundare R., 1973. An economic history of Nigeria 1860-1960. London: Methuen.

Ellis S. and J. Hine, 1995. The transition from non-motorised to motorised modes of transport. Paper presented at the 7th World Congress on Transport Research, Sydney, July 1995.

Fernando P. and G. Porter (eds), 2002. Balancing the load: gender and transport in low income economies. Zed, London.

Greene S., 1996. Gender, ethnicity and social change on the Upper Slave Coast: a history of the Anlo-Ewe. Heinemann, Portsmouth.

Grieco M., N. Apt and J. Turner, 1996. At Christmas and on rainy days: transport, travel and the female traders of Accra. Aldershot: Avebury.

Guyer J.I., 1997. An African niche economy: farming to feed Ibadan, 1968-88. Edinburgh: Edinburgh University Press.

Hill P., 1970. Studies in rural capitalism in West Africa. Cambridge: Cambridge University Press.

Kwamusi P., 2002. Safety and gender issues in rural transport in Busia District, Uganda. In P. Fernando and G. Porter (eds): Balancing the load: gender and transport in low income economies. Zed, London.

Overå R., 2006. Networks, distance and trust: Telecommunications development and changing trading practices in Ghana. World Development 34 (7), p. 1301-1315.

Overå R., 2008. Mobile traders and mobile phones in Ghana. In Katz JE ed.: The Handbook of Mobile Communication Studies, p. 43-54. Cambridge, MA: MIT Press.

Platteau J.-P., 1996. Physical infrastructure as a constraint on agricultural growth: the case of subSaharan Africa. Oxford Development Studies 24,3, p. 189-219.

Porter G., 1988. Perspectives on trade, mobility and gender in a rural market system: Borno, North-East Nigeria. Tijdschrift voor economische en sociale geografie 79, 2, p. 82-92

Porter G., 1994. Food marketing and urban food supply on the Jos Plateau, Nigeria: a comparison of large and small producer strategies under SAP. Journal of Developing Areas, 29(1), p. 91-110.

Porter G., 1995. The impact of road construction on women's trade in rural Nigeria. Journal of Transport Geography 3, 1, p. 3-14.

Porter G., 1999. Access to market opportunities in Ghana's off-road communities. Final Technical Report to the UK Department for International Development, May 1999.

Porter G., 2002. Living in a walking world: rural mobility and social equity issues in sub-Saharan Africa. World Development 30, 2, p. 285-300.

Porter G., 2008. Transport planning in sub-Saharan Africa. Progress report 2. Putting gender into mobility and transport planning. Africa Progress in Development Studies, vol 8, 3, p. 281-289.

Porter, G., 2011. 'I think a woman who travels a lot is befriending other men and that's why she travels': Mobility constraints and their implications for rural women and girl children in subSaharan Africa. Gender, place and culture 18 (1), p. 65-81. 
Porter, G., K. Blaufuss and F. Owusu Acheampong (2011). Filling the family transport gap in subSaharan Africa: young people and load carrying in Ghana. In L. Holt: Geographies of children, youth and families: an international perspective. London, Routledge, p. 189-202.

Porter G., Blaufuss K. and Owusu Acheampong F., 2012. Gendered patterns of IMT adoption and use: learning from Action Research. Research in Transport Economics. 34, p. 11-15.

Porter G., Hampshire K., Abane A., et al., 2012 in press. Child porterage and Africa's transport gap: evidence from Ghana, Malawi and South Africa. World Development.

Porter G., Harris F., Lyon F., Dung J., Adepetu A.A., 2003. Markets, ethnicity and environment in a vulnerable landscape: the case of small-scale vegetable production on the Jos Plateau, Nigeria, 1991-2001. Geographical Journal, 169, 4, p. 370-381.

Quagraine V. K.; Brandenburg S. G., Beliveau Y. J., 2009. Improving Labor-Based Road Rehabilitation in Ghana, Journal of Management Engineering 25, 2, p. 87-96.

Salifu M., 1994. The cycle trailer in Ghana: a reasonable but inappropriate technology. African Technology Forum 7, 3, p. 37-40.

Sieber N., 1997. An annotated bibliography on rural transport. London, IFRTD

Starkey P. 2001. Local transport solutions: people, paradoxes and progress. New York: World Bank, SSATP working paper no. 56, May 2001.

Stock E.A. and de Veen J., 1996. Expanding labour-based methods for road works in Africa. Washington DC: World Bank technical paper 347.

Thompson J.B., 2011. Africa's transport: a promising future. SSATP 1987-2011. Washington: World Bank/IBRD, 2011

Turner J., Hodgson F., Porter G., Mawdsley E., McCann G., 2011. Changing the game for Africa's infrastructure: what role for South-South cooperation? Unpublished paper, Uppsala: AEGIS conference, June 2011.

White, H.P. (1962). Communications and transport. In J.B. Wills (ed.), Agriculture and land use in Ghana. London: Oxford University Press.

CCRA National Archives of Ghana: Cape Coast Regional Archive Office

NAOA National Archives of Ghana: National Archives Office, Accra

PRO Public Record Office, London

\section{RÉSUMÉS}

This paper explores broad trends in road construction and associated transport services development in two West African countries, Ghana and Nigeria, over the last hundred years and considers their impact on the rural poor, with particular reference to rural women. It draws on diverse evidence, including twentieth century colonial archives, personal ethnographic field research undertaken over a 35- year period, associated quantitative surveys, and relevant secondary literature. Following an outline of each major phase in transport development, an assessment is made of its impacts on the rural poor, with particular reference to women. The study concludes with a review of recent donor policy shifts and the prospects for positive change. 
INDEX

Thèmes : Sur le Champ - Sur le Terrain

\section{AUTEUR}

\section{GINA PORTER}

Gina Porter, r.e.porter@durham.ac.uk, is Senior Research Fellow in the Department of Anthropology, Durham University, UK. 